\title{
Agriculture Challenges: Decline of Farmers and Farmland Study from Indonesian Family Life Survey
}

\author{
Della Ayu Anandita ${ }^{1}$, Kinanti Zukhrufijannah Patria ${ }^{2}$ \\ 1,2 Fakultas Ekonomi dan Bisnis Universitas Padjadjaran \\ Email: dellanandita24@gmail.com, kinanpatria96@gmail.com
}

\begin{abstract}
The challenge of agricultural sector in Indonesia nowadays is about land ownership which affected farmer's welfare. Farmers in aggregates are decreasing year by year, followed by decreasing farm land because of the land reform. Another story of farmer's income affected the land ownership of the farmers. Most of them choose to sell their own land to the land lords because of the lower income. And the lack of regeneration because farmers children choose to have a job outside agriculture sector. This paper is research about the real condition of Farmers in Indonesia between three factor of land ownerships, land reform, and lack of regeneration. Our investigation to secondary data show our hypothetical judgment: there is declining amount of farmers in Indonesia in community level. Meanwhile, that phenomenon support by evidence that there is declining farmland in community level. This study can be considering for policy implication in agriculture reform in Indonesia.
\end{abstract}

Keywords : land ownership, land reform, lack of farmer regeneration, farmer's welfare

JEL Classification: $Q 1, F 14$

\section{INTRODUCTION}

One of the cause is reduced availability of agricultural land due to land reform in Indonesia increasing every year commonly in the large province. As increased the number of people, demand for house also increased. Therefore, many of agricultural land used by developers to build real estate. Increase in the number of people also led to an increase demand for trade and tourism who participated increasing demand of land.

In this case, farmers could not be blame for selling their fields. The lack of education and technology, high agricultural cost management and the increased their needs forced farmers to sell their fields. Low level of education farmers in Indonesia make them have no other choice to work outside the agricultural sector, so for someone who do not own land they are being tenant farmers.

The increase in food prices should become heaven for farmers, because their income will be easily become higher. Unfortunately, it has become a boomerang for their welfare because most farmers in Indonesia is tenant farmers. Increasing food prices that occur is not have an impact on the welfare of farmers in Indonesia. Their income is remain low and they still have to buy their basic needs with the market price. Parties who were favoured in the increasing price are those who own land.

In addition, mindset of current public tend to think of farmers is not a worth job. Young generation is 
interested in work non-agricultural sector including occurring the farmer's child. This makes regeneration of farmers obstructed, as a result they prefer to sell their land to be set as capital or fare to work in non-agricultural sector.

Depend on introduction, the research consists of three main problems: How is the impact of land ownership on the agricultural sector in Indonesia? How is the impact of land reform on the agricultural sector in indonesia? How is the im-pact of lack in regeneration to the sustainability of the agricultural sector in Indonesia

\section{THEORETICAL FRAM- EWORK AND HYPO- THESIS}

In economics one way to optimize produce can be calculated by the theory of production functions. This theory can be used $\mathrm{s}$ as a reference in deciding how many input used to have optimal agriculture products. The theory of production functions in general formulated as follows :

\section{$Q(A, K, L)=F(A, K, L)$}

\author{
Explanation : \\ $\mathrm{A}=$ Technology \\ $\mathrm{K}=$ Capital (Land) \\ $\mathrm{L}=$ Labour (Farmers)
}

Based on formula above, the relationship between the results of agricultural products and variable input is positive. When the number of input used in production process increase, the output of production will rise and the opposite when input is reduced so that is also make output will be reduced. Variable input used in the process of agricultural production is labor (farmers), capital (land), and technology.

The agricultural sector in Indonesia faced several problems such as land ownership and the availability of land. According to AKATIGA, land in indonesia most owned by landlords, they accumulate the number of land by buying and pledge. Decision in the sustainability of the land is depend to landlords which lead on the decline in land productivity. The decline in land productivity will affect on declining farmers and land reform.

Conference tittled In the Zone with themes Feeding Asia: Innovation in Indo- Pacific Agriculture in May 2016 said a whole land used for the agricultural sector in Indonesia is $30 \%$ and only $43 \%$ of the land that could be planted. The most fertile land in Indonesia is on Java island which is causing 57 percent of the popu-lation of Indonesia prefer to stay in java. Because of that degradation land increased by $7 \%$.

Besides from the land ownership and the availability of land, other constraint on the agricultural sector is the decreasing the number of farmers from year to year (Susenas 2012 and 2014). According to Ben White (2012) one of the causes of the decreasing number of farmers in Indonesia is the lack of regeneration, that is where young labor (farm boy) which needed not want to work as farmer.

The cause of regeneration constraint of farmers are the lack of skill for the young generation especially who are in the village, the low on quality of life in rural areas, lack of government participation to advance the agricultural sector and village infrastructure and the lack of knowledge of the younger generation in the agricultural sector. These reasons make a lack of young generation interest to become farmers prospective 
candidate, so that the farmers was dominated by elderly age.

. The land ownership and the availability of the land can interfere the amount of agriculture output. The declining agriculture output will affect farmers welfare.

\section{RESEARCH METHODS}

Method used in this paper is descriptive. The available data will be analyzed further and conducted comparison with former research using different data.

In addition, this article used data from indonesian family life survey (IFLS) waves 4 and 5 and Survai Sosial Ekonomi Nasional ( susenas ) in 2012 and 2014.

IFLS data used to find the facts of the availability of land agriculture in more or less 220 sample village in indonesia. IFLS waves 4 held on the end of 2007 to the beginning of 2014. While ifls waves 5 carried out at the end of 2014 to the beginning of 2015 .

While Susenas data used to see the work force employed in agriculture, especially rice farmers

\section{ANALYSIS AND DISCUSSI- ON}

\section{Farmers in Indonesia}

Based on calculations of Susenas data, estimation of the amount of labor in indonesia in 2012 is about 115 million people, while estimation of the amount of labor in 2014 increased to 120 million people.

The following charts are from Susenas data and shows the number of workers on the agricultural sector from 2000 to 2015. The number of employment workers in agriculture sector for fifteen year is decreasing.
Figure 1 Employment by Productive Sector (\%) 2000-2015

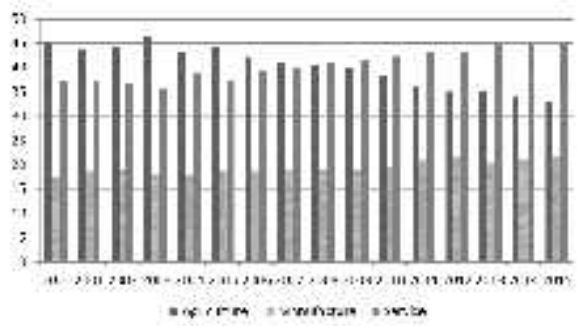

Source: Susenas, 2015

Table below showed the amount of labor in agriculture sector consisting of rice farmers, horticulture plantation, fisheries, livestock, and other in 2012 and 2014

Table 1 Amount of Agriculture Sector labor Indonesia in 2012 and 2014

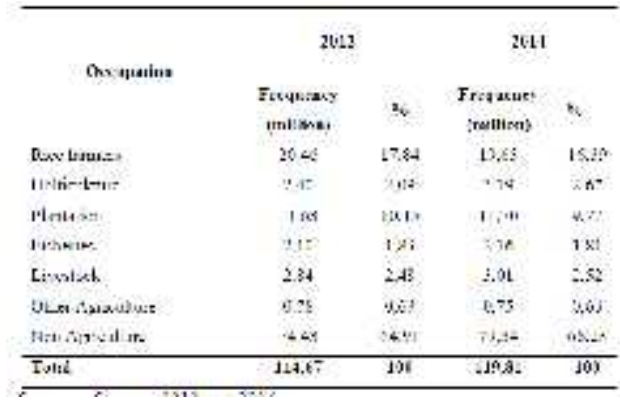

Source: Susenas 2012 and 2014

From chart and table above can be concluded that a decline in labor on the agriculture sector especially the amount of rice farmers from 20,46 million in 2012 become 19,63 million people in 2014 .

\section{Rural and Urban Farmers}

Based on Susenas mentioned that a decline in the number of farmers in an urban area of $0,54 \%$ of 2012 until 2014 .While in the rural a decline in the number of farmers of $2.31 \%$ in 2012 until the 2014. 
Figure 2 Number of Farmers 2012 and 2014

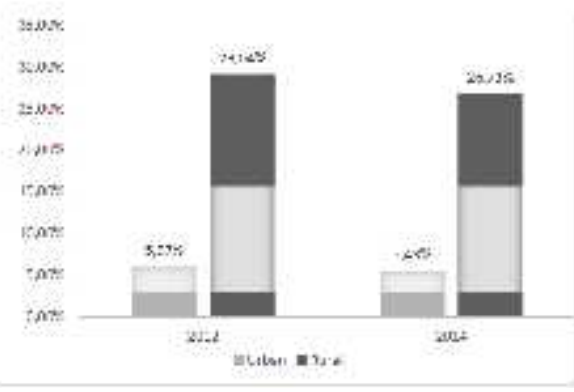

Source: Susenas 2012 and 2014

\section{Degradation of Land in Indonesia}

Figure 3 Percentage of Village 2007 and 2014

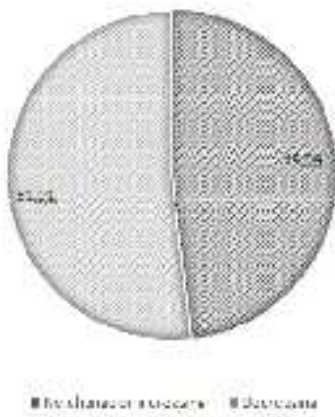

Source: Susenas 2012 and 2014

The Figure 3 above showed percentage of village with decreasing number of farmland. There are 183 similar villages in the sample in survey of 2007 and 2014. From 183 villages claimed to the number of farmland, there are 51,91 percent of villages with decreasing number of farmland.

\section{Land Reform}

The Figure 4 below shows that agricultural land reform most devoted to housing $38,79 \%$. While $26.7 \%$ for the road, 7,48\% for factories and $4,67 \%$ for other purposes. And the rest of $22,90 \%$ agricultural land are still survive.
Figure 4 Percentages of Farmland 2007

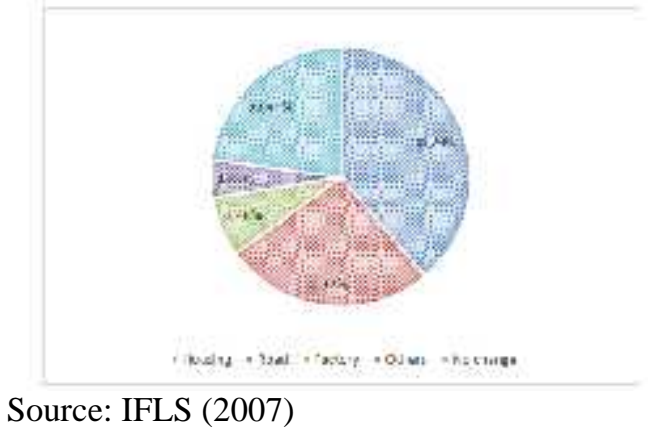

Figure 5 Percentages of Farmland 2014

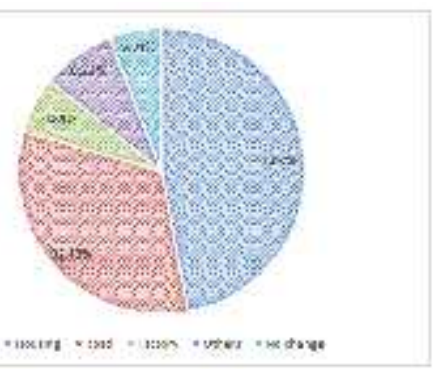

Source: IFLS (2014)

The Figure 5 above is the data on IFLS 2014 shows that in seven years, farmland which still survives only around $5.94 \%$. Over the area dominated for housing of $47,03 \%$, and the rest for the way $32,42 \%$, plant 6.39 $\%$, and for various other purposes of $8,22 \%$

From both figure can be summed up in the past 7 years, the amount of farmland which is experienced land reformed in total of 16,96 $\%$. Those farmland $8,24 \%$, switch into the housing and 5,72\%a changed into roads.

\section{Group of Farmers}

The Figure 6 below shows about age group farmers. Consisting of productive age group between 15 65 years old. In 2012 age group 3645 dominated. 
Age 2007

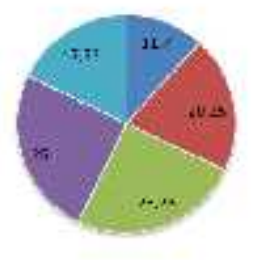

$=1$,

$=2035$

a $\$$ is 15

= 36 and

Source: Susenas (2012)

Figure 7 Percentages of Farmer Groups by Age 2014

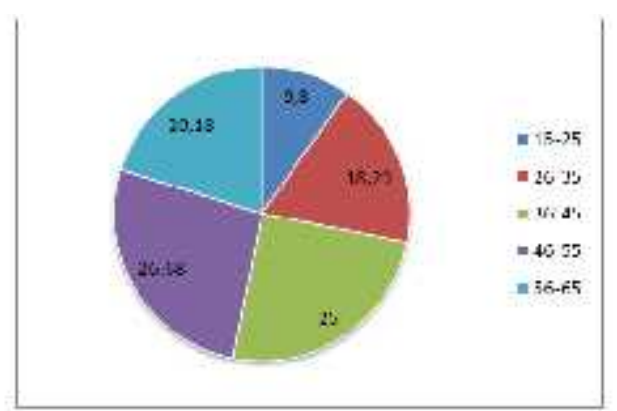

Source: Susenas (2014)

The Figure 7 is Susenas data on 2014. Having two years after, age group that work as farmers dominated by $46-55$ age group. It can be concluded that after two years, age group that work as farmers less attarcttive to among 15 - 45 years.

\section{CONCLUSION,IMPLICATION, SUGGESTION, AND LIMITATI- ONS}

The amount of farmers and availability of farmland decline each year. The declining number of farmers caused by the status of ownership of land is affected farmers welfare in indonesia which is generally low. Not only because the land ownership status, declining number of farmers also caused by the lack $f$ farmers regeneration. While the declining number of farmland caused by land reform.

Based on data IFLS 5 specify that in indonesia there are 15.000 households, $10 \%$ of households has land that is not used for general business activities or agriculture. Because of that we recommend an application to confront between the owner of land with the farmers which require land. This program aims to reduce the declining number of farmland and the lack of farmers regeneration.

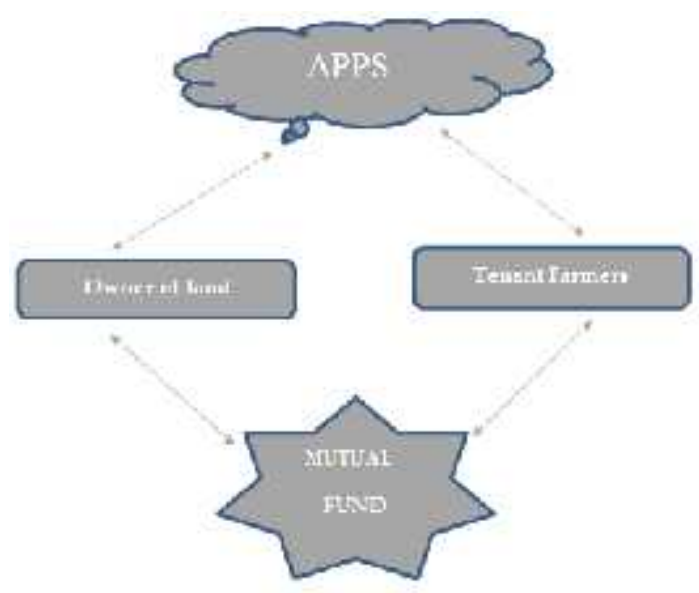

Assumptions:

1) There are land owners and the land consisting of cultivated land and empty land

2) There are tenant farmers who do not have land

3) Two parties provident to techno$\log y$

4) Unable to prevent owners to sell land

5) Increasing middle class income people which affected the demand of food to be increased.

Increasing population which accompanied by largest community income recent years is expected to increase until some decades forward. The increase in income make the middle class income community increase which will cause the demand of food also increase significantly. While the condition of indonesia until now have not been able to fulfill their food domestic needs.

Another constraint the farmland continued to decline from year to year. The diclining number of farmland was caused by several factors, 
One factor that most influential is increasing in land reform. Hence needed a solution to prevent declining amount of farmland every year and expected to be increased because there are a lot of unproductive empty land.

The solution of the declining land and lots of unproductive land is confront owners land with tenant farmers who do not have land to have a beneficial partnership. Land owners criteria can be an old farmer which want to retire of their job, or not farmers but they have unproductive or empty land. Tenant Farmers can be a productive farmers, or not farmers which still want to develope the farmland.

Along with the technology development which can make it easier for people to communicate with others, an application can be used as a possible solution to be applied. Land owners that have been registered to the applications can meet the tenant farmers directly.

Capital used to cultivate the land can come from the land owners or tentant farmers, it is in accordance with the agreements by both parties. Capital problems also can be submitted to third parties which is mutual fund institution. Profits obtained both parties can be done with sharing system which is beneficial for boh parties.

The form of cooperation that can be done among others :

The land owners hand over their land to tenant farmers in use capital of tenant farmers. The land owners hand over their land to tenant farmers in use capital of the land owners The land owners hand over their land to the tenant farmers in use capital from mutual fund institution in the name of tenant farmers management. The land owners hand over their land to tenant farmers in use capital of the mutual fund institutions in the name of the land owners

\section{REFERENCES}

Badan Pusat Statistik (2007, 2012, 2015), Susenas Data laman microdata.bps.go.id/mikrodata/index.php /catalog/653 diakses 8 Agustus 2016

Perth USAsia Centre. (2016).

Feeding Asia: Innovation in IndoPasific Agriculture. Australia: Perth US Asia Centre.

Ricky, H.H., \& Aprilia, A. (2013). Tanah Untuk Penggarap? Penguasaan Tanah dan Struktur Agraris di Beberapa Desa Penghasil Padi, JurnalAnalisisSosial, 19 (1).

SurveyMeter (2007, 2014), The Indonesian Family Life Survey (IFLS)surveymeter.org/research/ 3/iflseast diakses 15 Agustus 2016

White, Ben. (2012). Agriculture and The Generation Problem: Rural Youth, Employment, and The Future of Farming, IDS Bulletin, 43 (6), pp. 9-19.

Yograprasta, A.N., \& Rina, H. (2013). Menguak Realitas Orang Muda Sektor Pertanian di Pedesaan, Jurnal Analisis Sosial. 19 (1). 